した場合, また体位を変えた時, どの程度の濃度の一定 した写真が得られるかを試み，その実用性について検討 した.

[装置及び材料]

日立診療用 X線装置 DR-125A 型, 透視台TM-20-11, 水ファントーム, MIXD ファントーム, 鳴海製作所製濃 度計,

〔構造】

制御船上の Auto スイッチを入れることにより，図 1 のように並べて取付けてあるマイクロスイッチが蛍光板 の前後移動により，移動動作し撮影電圧が変化する。ま た监光板前面には電圧を $4 \mathrm{kVp}$ おきに 5 段切換出来るツ マミがあり,それにより食道部, レリーフ像, 充えい像 等の場合の調整が出来るようになっている.

[方法及び結果]

透視台を横にして蛍光板と透視台の間にポリエチレン の箱を置き，その中に水を入れ $13 \mathrm{~cm}$ から $33 \mathrm{~cm}$ までの 厚さを変え撮影し, 同一濃度が得られる電圧を求めた。 また MIXD ファントームの板を重ねて同樣にして行な った。図2.また装置の実際の電圧変化は図 3 汇示す。 [考察]

蛍光板を患者汇密着させて撮影するために腹部が胸部

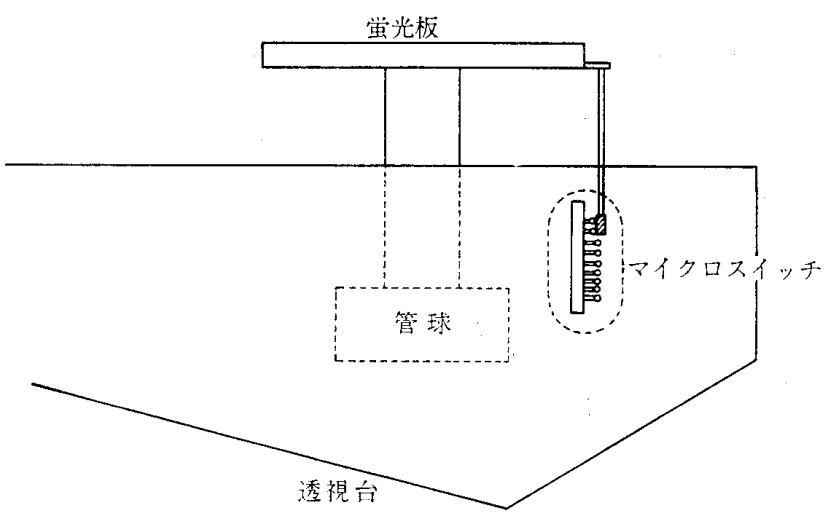

図 1

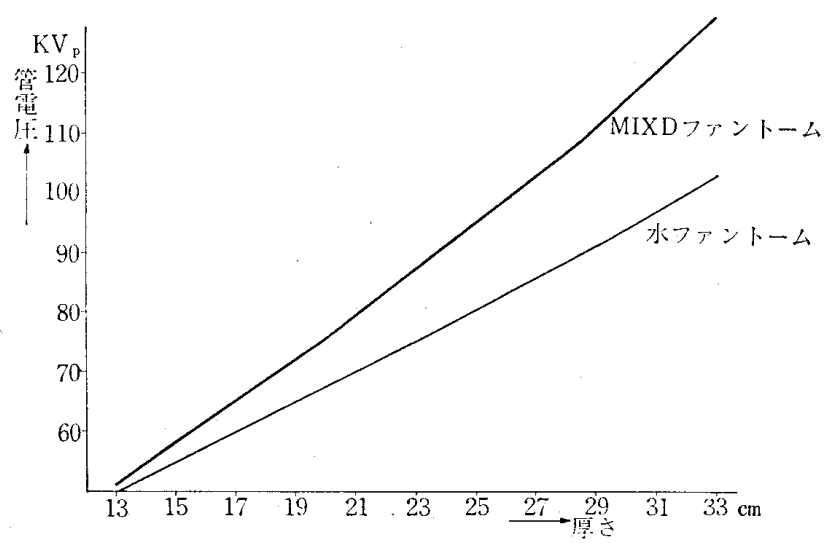

図 2

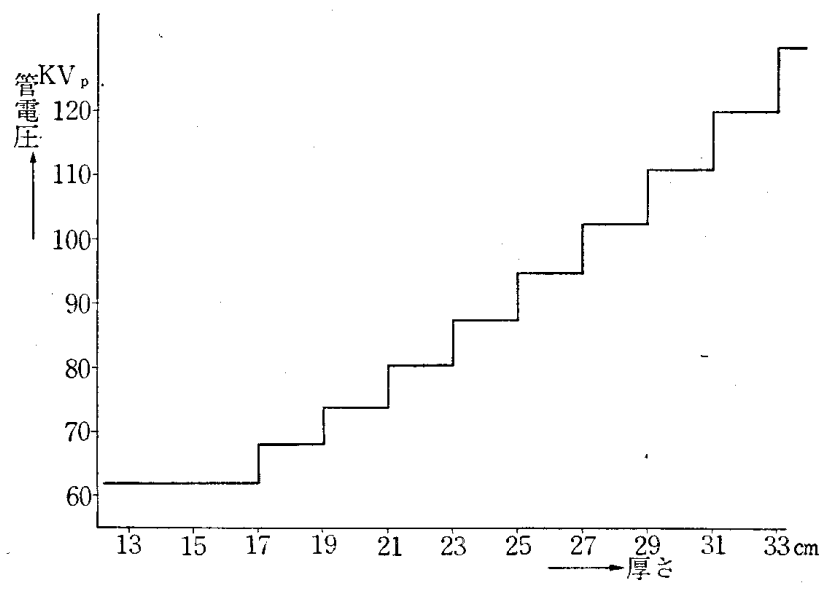

図 3

に比し極端に薄い人や背椎の䇾曲した老人等に使用した 場合, また人により体質, 性別, 年令等によりある程度 の濃度差を生ずるのはさけがたいが，診断佂值がないと いうことは少なかった。しかし自動現像機が多く使用さ れている今日に於ては電圧調整が $2 \mathrm{~cm}$ 間隔で行なわれ ているのは不適で今後は $1 \mathrm{~cm}$ 間隔で行なうのが望まし いと考えられる。

\section{7. 診療船済生丸の紹介}

1. 建造の趣旨

岡山済生会総合病院

山崎 進・渡部 一秀 宇佐美政栄・船 田 基 山田 清彰・竹原 聡史

高松宮殿下を総裁に仰ぐ，社会福祉法人（恩賜財団） 済生会の本来の使命は，医療汇恵まれない人達に暖い手 を差し伸べる事にある．創立50周年を記念して従来まで 幾回となく実施して来た僻地診療対策を更に強力に押し 進めるべく彰療船を建造し，その名む済生丸とし瀬戸内 百万にむ及ぶ，無医島，臨海特別僻地住民の期待と希望， そして済生会の新りにむ似た使命を満載して昭和 37 年 10 月就航した.

2. 構造並び性能

本船々体は鋼鉄性で，今治市来島ドック KK に上り昭 和37年10月竣工した。

総 旡数 74.59 雷 船長 $20 \mathrm{~m}$

満水吃水 $\begin{aligned} & \mathrm{F} 1.80 \mathrm{~m} \\ & \mathrm{~A} 2.40 \mathrm{~m}\end{aligned}$ 船幅 $5 \mathrm{~m}$

速力毎時 10 哩

エンジン 250 馬力, 赤坂, 6 気筒

下甲板 エンジンルーム船員室, 看護婦室

中甲板 患者待合室, X線室, 検查室, 誩療室, 薬局 食堂, 浴室 
上甲板 操舵室, 船長室, 無線室

乗 組 員 船長他 5 名

電 源 $200 \mathrm{~V} \quad 7.5 \mathrm{kVA}$ 発電機 2 台

3. 搭載医療機器

動く総合病院にしようとの意図から, 中都市の 300 床 程度の病院に必要な器械を搭載している.

(1) X線関係

(亿) (間接) 蓄電器放電式 $\mathrm{KCD}-10$ 特型

$\lceil 100 \mathrm{kV} 1 \mathrm{MF}$ 三極回転陽極管, 波尾切断, 天 板スライド, モータ一駆動倒立, 透視可能防護 ボックス,キャノン $70 \mathrm{~mm}$ 長尺 (400枚撮) 自 動力メラコ

(口) (直接) 切換スイッチによる

〔モーター駆動式透視撮影台, 回転陽極管によ り“トモ”を除くあらゆる撮影が可能である】

(メ) ポータブルX線装犆 P.K-40 1 型 1 台

(2) 臨床検査用器械

生物顕微鏡, 光電光度計, 心電計; 電気遠心沈澱 器 血色素計, 蛋白計, 尿比重計, 電気冷蔵庫等々

(3) この他の検診用器械, 器具

眼科用，試視力表，色盲表，各種検眼鏡

耳鼻科用 吸引器, 額帶鏡, 耳鏡等

一般检診用 体重計, 血圧計, 各種消毒器, 肺活量計, 涯物罐等

薬局関係 各種乳鉢, 各種薬匙 各種液量誩, 各種装 置等

4. 船舶の運営, 配船, 要領

本船は済生会本部の所有しし（船籍東京港停泊港松山 港）運営は本部と中四国ブロックの四県支部よりなる運 営委員会の下に, 連絡委員会を置き, 岡山に連絡事務所 を，松山に管船事務所を置いて配船スケジュールにより， 岡山, 広島, 愛媛, 香川の四県に属方る無医島, 臨海特 別僻地を夫々相協力して円滑なる医療検搒の央を挙げよ うとするものである。

\section{8. 線量計を利用したX線装置相互較正法}

\section{舄津製作所} 田中 義宗

撮影系の標準化の一つとしてX線装置の出力の管理の 問題がある.X線装置の出力を相互較正する方法として 線量計法，フィルム法. 実測（ボールギャプなど）法等 が考えられる、X線写真によって行なう方法は夷際的で あるが再現性が㲹し，不便である。一方線量計による 方法は信頼度が高く, 再現性に富み, 線量計 (Victreen Condenser r-meter) があれば手軽に行なえる。 また撮
影領域一回のばく射線量が測定できる．測定した線量透 過特性はX線写真効果を示すためX線写真の評洒に有用 である。

管電圧図表に基づいて基準管電流 $100 \mathrm{~mA}$ について線 量透過特性を作成する. 各管電流については同一管電圧 のもとで同一線量，同一コントラストの点を結んで基準 となる管電圧図表を修正し，作成する。乙のX線装置を 標準のX線装置とし，較正しようとする装置で線量透過 特性を作成し，標準のカーブと重ね合わせて管電圧差を 読み取る.この方法では $\pm 2 \mathrm{kVp}$ の精度まで近づけると こができる。

線量透過特性の解析をすると

1）縦軸の $\mathrm{mr} / \mathrm{mAs}$ は装置相互間の絶対的な出力差 を表わし，曲線の絶対值が同一管電圧のもとで上にあれ ばそれだけ短時間撮影ができ X線写真はシャープになる.

また管電圧波形による出力差やコンデンサ装置のよう に容量に制限を持ったすのは縦軸の線量に制限があると とになり，全波整流装置等は撮影時間を延せば縦軸の倍 率は制限がなくなる．そして実際に使用する $\mathrm{mAs} の \mathrm{mr}$ は縦軸を倍率すると決めるととができる。

2) 横軸は被写体の愿さ（Al）を示し，フィルターの うすいととろでX線管の固有フィルタ一の相異がわかる. $\mathrm{X}$ 線装置の出力を決める場合はフィルターの厚さが大切 になる。

3. 曲線の傾きはX線写真のコントラストを表わす。 管電圧波形沉脈動の少ないものはコントラストが覀く， 全放電形のコンデンサ式装置などは曲線の傾きが急でコ ントラストがよいととを意味する．とのようにX線装置 の本質的な相異を表現するととができる.

4）撮影条件選択の難易さがわかる.

曲線の傾きは線コントラストすなわち診断を必要とす る愿さの範囲に刘するラチチュードを現わし, 曲線の傾 きが急なむのは撮影条件の選択がむづかしい。

5）曲線と曲線との間腺から管電圧の相異がわかる。

線量透過特性を重稀て曲線のズレから管電玨の差を見 出すとよができる。

\section{翼問}

電圧波形が違うとき減弱曲線を如何に較正するか。 （東京 横田 純一)

\section{管}

線量透過特性の縦軸の差は同一管電圧の場合管電圧波 形の差による出力差を表わしている.

\section{啠問}

コンデンサ式波尾切断の場合（線質が時間と共に変化 